\title{
Comparative study of SNI 1726:2012 and SNI 1726:2019 guidelines for response spectrum 2D method (study case: GKT II building of Bengkalis State Polytechnic)
}

\author{
Zev Al Jauhari ${ }^{*}$, Addini Khafifah Nur ${ }^{1}$, Ridho Aidil Fitrah ${ }^{2}$, and Siska Apriwelni ${ }^{3}$ \\ ${ }^{1}$ Civil Engineering Department, Bengkalis State Polytechnic, 28711 Sungai Alam, Bengkalis, Riau \\ ${ }^{2}$ Civil Engineering Department, Andalas University, 25166 Limau Manis, Padang, West Sumatera \\ ${ }^{3}$ Civil Engineering Department, Sumatera Institute of Technology, 35365 Way Huwi, South Lampung, Lampung
}

\begin{abstract}
A standard code for designing earthquake-resistant buildings in Indonesia has always improved and updated year by year. It starts 1983, SNI 1726:2002, SNI 1726:2012, and the latest one SNI 1726:2019 Standard Codes. There is a procedure scope change for designing seismic load to become wider due to the adoption of a new standard, SNI 1726:2019. This research aims to compare the building design by using the response spectrum 2D method of SNI 1726:2012 and 2019 to determine the safety of existing buildings that use the old code. The structure of the building is modelled as a classroom and office building with a height of $15.50 \mathrm{~m}$ in Bengkalis State Polytechnic, Riau Province, namely Gedung Kuliah Terpadu (GKT) II Building. The reviewed structure behaviors are internal forces (bending moment, shear, and axial forces) on the structural elements (beams and columns). The result is directly proportional to rising in $\mathrm{S}_{\mathrm{DS}}$ and $\mathrm{S}_{\mathrm{D} 1}$ by $3.60 \%$ and $19.02 \%$, respectively. By this rising, it affects the response spectra graph that has increased in SNI 1726:2019. The results prove that the change of design by using SNI 1726:2012 to 2019 has an effect, even though the calculation of the building structure forces still uses the old codes, but it meets the safe limits using designing with the SNI 1726:2019 method. This paper also compares the design of the structural elements by using SNI 2847:2019 codes with the planning of the existing building before. Overall, the building structure can be classified as able to withstand seismic force based on the new standard method.
\end{abstract}

\section{Introduction}

The codes for the seismic-resistant building structure have a primary role to ensure building safety. The earthquake caused building collapse has exceeded the predictions of the building regulations in Indonesia in the last decade. The unpredicted large force earthquake caused damage to severe buildings occurred in Aceh, Padang, and Yogyakarta [1]. This was influenced by the PGA increase that is greater than the value in the older code, SNI 1726:2012 [2].

In 2019, a new code on procedures for seismic resistance planning for structures of building and nonbuilding, SNI 1726:2019, has ratified by the Government of Indonesia as a revision of SNI 1726:2012 [3]. The release of a new code has changed the procedure scope for determining and designing seismic loads to become wider. The acceleration response spectrum at the building location is one of the important scopes of information needed for designing the seismic resistance structure building [4].

An increase in Peak Ground Acceleration (PGA) may cause by the changes in the seismic hazard map that consequently increases the seismic design load. An existing building planned with older earthquake codes requires evaluation as a consequence of this seismic design load increase. Higher load demand should be investigated subjected to the performance of those buildings to determine if they need any strengthening [5].

Seismic parameters must be considered in planning and designing development in Indonesia. The ground acceleration is one of the earthquake parameters that directly affect the seismic load design because seismic waves act on the building period. The building structure must be designed as a seismic-resistant building to secure the building. It must be planned following the applicable seismic regulations in Indonesia. By modeling and analyzing the building model impacted by earthquake loads; the damage of buildings can be minimized so that planners can better design the building to construct [6].

An earthquake is a result of the sudden release of stored energy in the Earth's crust that comes from a wave in a place and spreads in all directions [7]. In SNI 1726:2012, the PGA and response spectrum acceleration for 0.2 seconds (short periods) and 1 second periods with a probability of $10 \%$ exceeding in 50 years $(500$ year return period), and maybe $2 \%$ exceeding in 50 years $(2500$

*Corresponding author: zevaljauhari@polbeng.ac.id 
year return period). While in the new code, the PGA and acceleration of the response spectrum for 0.2 seconds and 1 second periods with a probability of $7 \%$ exceeded in 75 years (1000 return period years), and a $2 \%$ probability is exceeded in 50 years (2500 year return period). The 251 faults were inputted as a PSHA (Probabilistic Seismic Hazard Analysis) of the source of seismicity [8].

With the changes in the standard codes, it is necessary to find out how much the earthquake response factor changes from the old standards that affect the value of the seismic load, the deviation magnitude between the floors, and the extent to which the load difference affects the calculation of structural dimensions [9]. For this reason, a comparative analysis was carried out between SNI 1726:2012 and SNI 1726:2019. Comparison of earthquake loads applied to a 3-story building model and the force analysis results from each of these standards is calculated to determine the feasibility of the profile dimensions and reinforcement requirements [10]. In this study, a 3-story classroom and office building in Bengkalis, Riau, Indonesia which was designed using SNI 1726:2012 and SNI 2847:2013 as older Indonesian seismic code and concrete code, respectively, was chosen to be investigated.

\section{Methodology and Modelling}

\subsection{Considered Building}

The change in spectrum response in the GKT II Building of Bengkalis State Polytechnic that is still designed using SNI 1726:2012 and compared with SNI 1726:2019 was checked and evaluated in this study. After determining the spectrum response followed by the running model in SAP2000 with the dynamic method (2D response spectrum), it compares the values of the internal forces of columns and beams. Fig. 1 shows the typical structural plan view of the considered building. In general, the design and analysis were consist of modelling structure, defining material properties and frame section, then calculation and determination of loading and analysis model of the structure. Fig. 2 shows the 3D model of the considered building.

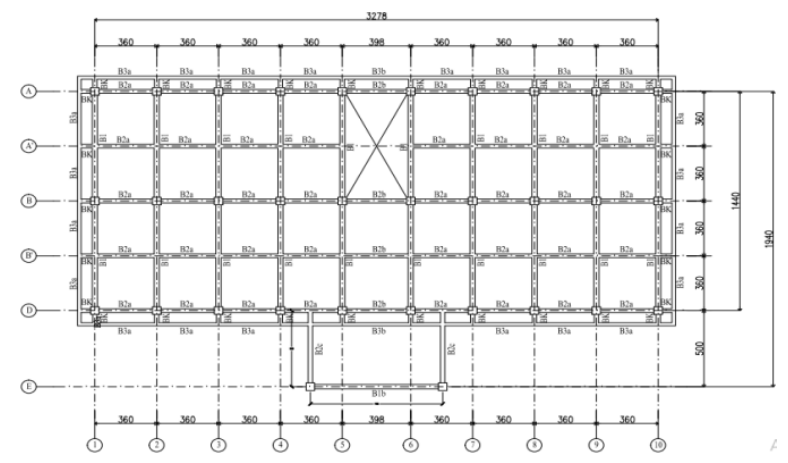

Fig. 1. Typical structural plan view of the GKT II Building.

Preliminary data such as soil investigation, as-built drawing, technical structure, and earthquake data were used to build the model. GKT II Building withstands structural loads based on SNI 2847- 2013. The building is a reinforced concrete structural system with a mini pile as the foundation. The compressive strength of concrete $\left(\mathrm{f}_{\mathrm{c}}\right)$ used is $25 \mathrm{MPa}$ for all upper structure elements, there are, beam, slab, column, and pile. The rebar strength $\left(f_{\mathrm{y}}\right)$ for longitudinal and transversal rebars are $400 \mathrm{MPa}$ and 240 $\mathrm{MPa}$, respectively.

The dimension of the primary beam is typical for all structural models. Beam B1 $300 \mathrm{~mm} \times 600 \mathrm{~mm}$ is used for a $7 \mathrm{~m}$ span and Beam B2 $250 \mathrm{~mm} \mathrm{x} 400 \mathrm{~mm}$ for a $3.5 \mathrm{~m}$ span. The dimension of columns is $500 \mathrm{~mm}$ x $500 \mathrm{~mm}$ for all stories model. The thickness of the slab is typically 120 $\mathrm{mm}$ for all stories. The building is a reinforced concrete structure with a height of 3 -stories building + roof $(\mathrm{h}=$ $15.50 \mathrm{~m}$ ). The building was analyzed with a seismic load for soft soil (SE). The structure of the 3-story office building consists of a medium moment resisting frame system for Seismic Design Category C.

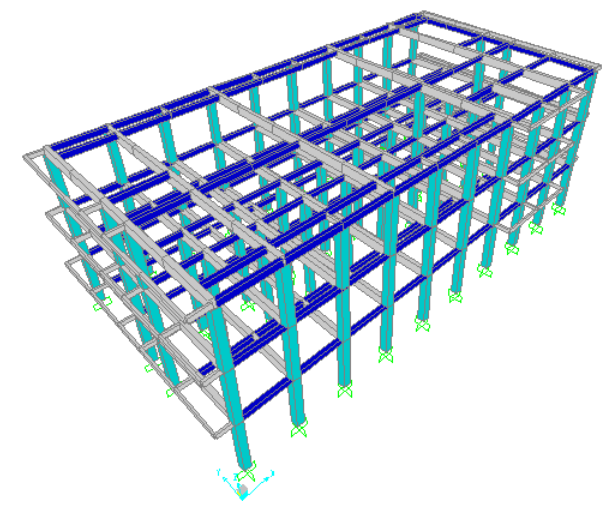

Fig. 2. 3D Model of the considered building.

\subsection{Loads}

There are two types of loading are used in this study, a) gravity load which includes dead and live loads, and b) lateral load (earthquake load).

\subsubsection{Gravity Loads}

Table 1. Type and value of loads.

\begin{tabular}{|c|c|c|}
\hline Type of Load & Description & $\begin{array}{c}\mathbf{Q u} \\
\left(\mathbf{k g} / \mathbf{m}^{\mathbf{2}} \mathbf{)}\right.\end{array}$ \\
\hline Dead Load & Slab (Reinforced Concrete) & 288 \\
\hline Super Dead Load & $\begin{array}{c}\text { Space + Ceiling + Floor } \\
\text { Tiles + MEP }\end{array}$ & 110.5 \\
\hline $\begin{array}{c}\text { Super Dead Load } \\
\text { for Roof }\end{array}$ & $\begin{array}{c}\text { Aluminum Composite } \\
\text { Panel + Frame }\end{array}$ & 11.76 \\
\hline \multirow{2}{*}{ Live Load } & $\begin{array}{c}\text { Meeting Room, } \\
\text { Laboratories, }\end{array}$ & 400 \\
\cline { 2 - 3 } & Offices & 250 \\
\cline { 2 - 3 } & Toilet & 200 \\
\hline $\begin{array}{c}\text { Live Load for } \\
\text { Roof }\end{array}$ & Forridor Slab and Water Tank & 254 \\
\hline
\end{tabular}

Gravity loads represent all tributary dead and live loads. The dead and live loads are based on PPIUG 1983 and PPURG 1987 that refer to SNI 2847:2013. The detail 
of gravity loads that work as distributed loads are shown in Table 1 and Fig. 3.

\subsubsection{Lateral Load}

This study has focused on the seismic load by using the response spectrum 2D method of SNI 1726:2012 and SNI 1726:2019 as the lateral load.

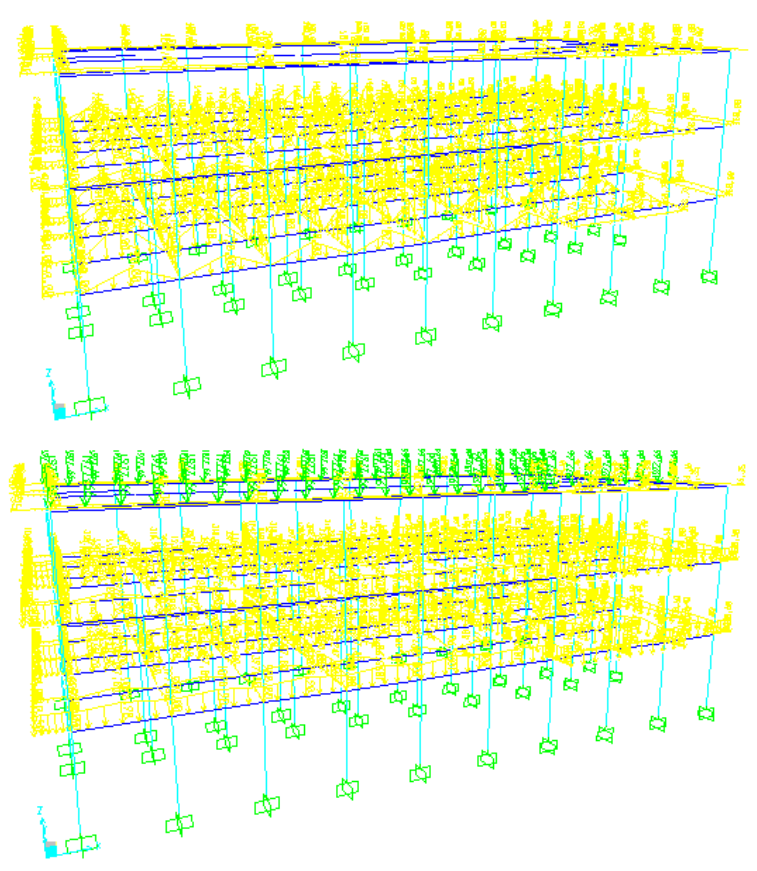

Fig. 3. Dead and live loads input on the considered building.

\subsection{Load Combinations}

Structural members should design to have strength for all sections at a minimum required strength calculated for the load and factored in combination according to the standards. The load combinations according to SNI 1726:2012 and 2019 are seen in Equations $1-6$.

$$
\begin{aligned}
& U=1,4 D \\
& U=1,2 D+1,6 L \\
& U=1,2 D+1 L+1 E v+1 E h \\
& U=0,9 D-1 E v+1 E h
\end{aligned}
$$

With the Ev (vertical earthquake) and Eh value (horizontal earthquake) values as follows:

$$
\begin{gathered}
E \mathcal{V}=0,2 S D \\
E h=\rho Q_{E D S}
\end{gathered}
$$

\section{Results and discussions}

The design spectrum response by using SNI 1726:2012 and SNI 1726:2019 will be used in the analysis comparison. To take into account the influence of internal forces on structural elements, the design response spectrum is required. The longest transverse side to be given evenly distributed load is selected to be part reviewed; it was shown in Fig. 4. Dynamic analysis for earthquake-resistant structures design is carried out. It is needed for a more accurate evaluation of the earthquake forces acting on the structure, also to determine the structural behavior due to the earthquake effects [11]. The method of spectrum response in SNI 1726:2012 and 2019 codes is used to obtain the spectrum response graphs. The data and values obtained are then inputted into SAP2000 to get the graphs of spectrum response.

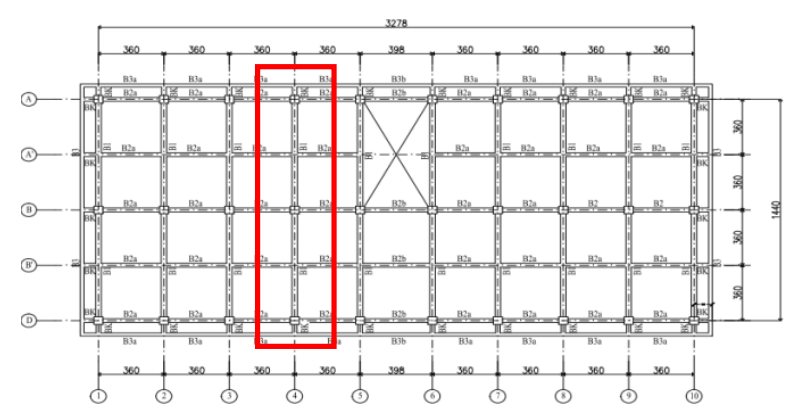

Fig. 4. Point of view on the structural building.

\subsection{Response Spectrum Specified in SNI 1726:2012 and SNI 1726:2019 Codes}

The steps of the design of spectrum response according to SNI 1726:2012 and SNI 1726:2019 in a way that has been adjusted to the study needs [11]:

- Look and observe the considered building location

- Determine the value of SPT and the type of soil classification

- Define the acceleration parameters of MCER (Maximum Considered Earthquake, Risk Targeted) for short periods of 0.2 seconds $\left(\mathrm{S}_{\mathrm{S}}\right)$ and 1.0 seconds $\left(\mathrm{S}_{1}\right)$

- Look for the amplification factor of the response parameters of the ground surface acceleration spectrum for short periods $\left(\mathrm{F}_{\mathrm{a}}\right)$ and 1 second period $\left(\mathrm{F}_{\mathrm{v}}\right)$.

- Define the acceleration spectrum response parameters $\left(\mathrm{S}_{\mathrm{MS}}\right.$ and $\left.\mathrm{S}_{\mathrm{M} 1}\right)$ using this eq.:

$$
S_{\mathrm{MS}}=F_{\mathrm{a}} x S_{\mathrm{s}}
$$$$
S_{\mathrm{M} 1=} F_{\mathrm{v}} \times S_{1}
$$

- Calculate the design acceleration spectrum response parameters $\left(\mathrm{S}_{\mathrm{DS}}\right.$ and $\left.\mathrm{S}_{\mathrm{D} 1}\right)$ using Equations 9 and 10 .

$$
\begin{gathered}
S_{\mathrm{DS}}=2 / 3 \times S_{\mathrm{MS}} \\
S_{\mathrm{D} 1}=2 / 3 \times S_{\mathrm{M} 1}
\end{gathered}
$$

- Draw a response graph to images with the provisions that have been determined in SNI 1726:2012:

a. For $\mathrm{T}<\mathrm{T}_{0}$, the $\mathrm{S}_{\mathrm{a}}$ (design acceleration response spectrum) must be taken from Equation 11.

$$
S_{\mathrm{a}}=\mathrm{S}_{\mathrm{DS}}\left(0,4+0,6 .\left(\mathrm{T} / \mathrm{T}_{0}\right)\right)
$$

b. For $\mathrm{T}_{0} \leq \mathrm{T} \leq \mathrm{T}_{\mathrm{s}}$, the response spectrum of the design is $\mathrm{S}_{\mathrm{a}}=\mathrm{S}_{\mathrm{DS}}$.

c. For $\mathrm{T}>\mathrm{T}_{\mathrm{S}}$, the $\mathrm{S}_{\mathrm{a}}$ is taken for Equation 12 .

$$
S_{\mathrm{a}}=\mathrm{S}_{\mathrm{D} 1} / \mathrm{T}
$$

- Draw a response of graph to images based on the provisions determined in SNI 1726:2019. Period provisions are as follows:

a. For $\mathrm{T}<\mathrm{T}_{0}$, following Equation 11 .

b. For $T_{0} \leq \mathrm{T} \leq \mathrm{T}_{\mathrm{s}}$, the spectral response of the design acceleration is $\mathrm{S}_{\mathrm{a}}=\mathrm{S}_{\mathrm{DS}}$

c. For $\mathrm{T}_{\mathrm{S}}<\mathrm{T} \leq \mathrm{T}_{\mathrm{L}}$, the spectral response of the design acceleration is taken Equation 12.

d. For $\mathrm{T}>\mathrm{T}_{\mathrm{L}}$, the $\mathrm{S}_{\mathrm{a}}$ is taken based on Equation 13 . 


$$
S_{\mathrm{a}}=\left(\mathrm{S}_{\mathrm{D} 1} \cdot \mathrm{T}_{\mathrm{L}}\right) / \mathrm{T}_{2}
$$

e. The $T$ value is obtained by calculating the $T_{a}$ (fundamental period of the structure) based on Equation 14.

$$
T_{\mathrm{a}}=\mathrm{C}_{\mathrm{t}} \cdot \mathrm{h}_{\mathrm{n}} \mathrm{X}
$$

$\mathrm{h}=$ the structure's height (m) above the base to the structure highest level.

f. The $T_{0}$ and $T_{S}$ values can be obtained from Equations 15 and 16.

$$
\begin{aligned}
& T_{0}=0,2 . \mathrm{S}_{\mathrm{D} 1} / \mathrm{S}_{\mathrm{DS}} \\
& T_{\mathrm{S}}=\mathrm{S}_{\mathrm{D} 1} / \mathrm{S}_{\mathrm{DS}}
\end{aligned}
$$

g. $T_{L}$ values are obtained from SNI 1726:2019 in Fig. 20.

h. The GKT II building is categorized as IV in determining the risk category of buildings, and the earthquake priority factor is 1.50 in earthquake priority factors.

i. The seismic design categories determination is based on the acceleration response parameters category of seismic design in the 0.2 and 1 second periods

The spectrum response graphs in Fig. 5 are obtained from SNI 1726:2012 and 2019 methods.
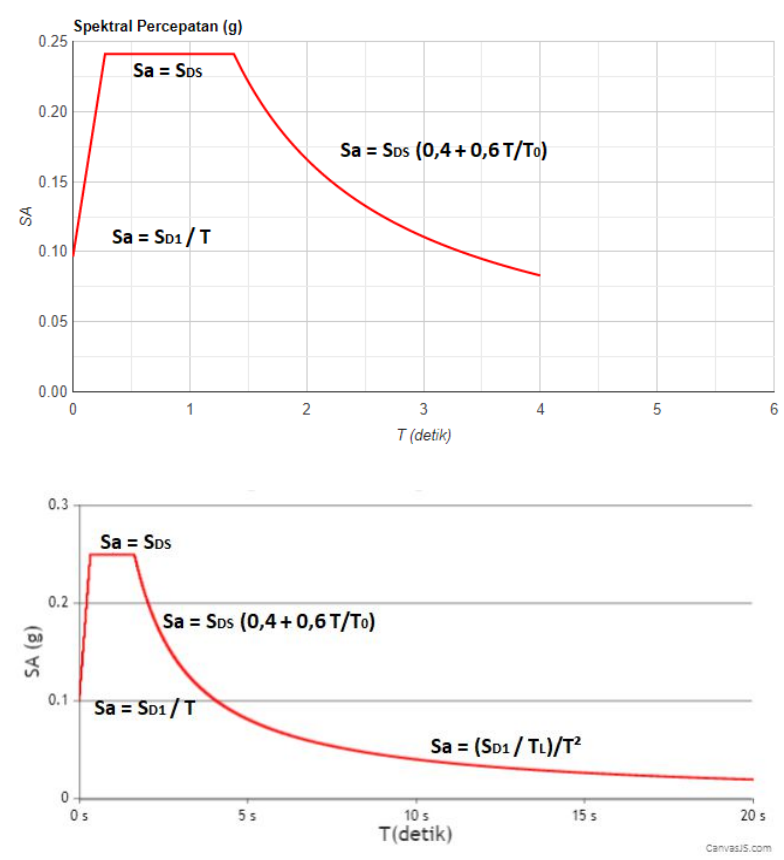

Fig. 5. Response spectrum design for Bengkalis Regency based on SNI 1726:2012 and SNI 1726:2019 (Soft Soil).

As a result of the increase in the $\mathrm{S}_{\mathrm{DS}}$ value in $\mathrm{SNI}$ 1726:2019 which is used as a parameter for calculating vertical earthquakes, the calculation of earthquake loads in SNI 1726:2019 also increases, as seen in Table 2. The combination of loading is per the parameters contained in SNI 1726:2012 and SNI 1726:2019. Then calculated on the load combination due to vertical earthquakes to obtain 18 combinations of loading used. The combination of loading consists of dead load, live load, vertical earthquake load, and horizontal earthquake load that can affect the building. The following is a comparison of the loading combination on SNI 1726:2012 and 2019 is shown in Table 3.

Table 2. The parameter value of spectral response graph based on SNI 1726:2012 and 2019.

\begin{tabular}{|c|c|c|}
\hline Parameters & SNI 1726:2012 & SNI 1726:2019 \\
\hline $\mathrm{S}_{\mathrm{D} 1}$ & 0,332 & 0,41 \\
\hline $\mathrm{S}_{\mathrm{DS}}$ & 0,241 & 0,25 \\
\hline $\mathrm{T}_{0}$ & 0,275 & 0,33 \\
\hline $\mathrm{T}_{\mathrm{S}}$ & 1,377 & 1,64 \\
\hline $\begin{array}{c}\mathrm{Sa}=\mathrm{S}_{\mathrm{DS}} \\
(0,4+0,6 \mathrm{x} \\
\left.\mathrm{T} / \mathrm{T}_{0}\right)\end{array}$ & 0,376 & 0,342 \\
\hline $\mathrm{Sa}=\mathrm{S}_{\mathrm{DS}}$ & 0,241 & 0,25 \\
\hline $\mathrm{Sa}=\mathrm{S}_{\mathrm{D} 1} / \mathrm{T}$ & 0,623 & 0,769 \\
\hline $\mathrm{T}$ & 0,533 & 0,533 \\
\hline $\mathrm{T}_{\mathrm{L}}$ & & 20 \\
\hline
\end{tabular}

Table 3. The load combinations on SNI 1726:2012 and 2019.

\begin{tabular}{|l|l|l|}
\hline \multicolumn{1}{|c|}{ SNI 1726:2012 } & \multicolumn{1}{|c|}{ SNI 1726:2019 } & \multicolumn{1}{|c|}{$\begin{array}{c}\text { Percentage } \\
\text { of } \\
\text { difference } \\
(\%)\end{array}$} \\
\hline \multicolumn{3}{|c|}{ Load combination of non- earthquake } \\
\hline $1.4 \mathrm{D}$ & $1.4 \mathrm{D}$ & - \\
\hline $1.2 \mathrm{D}+1.6 \mathrm{~L}$ & $1.2 \mathrm{D}+1.6 \mathrm{~L}$ & - \\
\hline \multicolumn{2}{|c|}{ Load combination with earthquake } \\
\hline $1.2 \mathrm{D}+1 \mathrm{~L}+\left(\mathrm{E}_{\mathrm{h}}+\right.$ & $1.2 \mathrm{D}+1 \mathrm{~L}+\left(\mathrm{E}_{\mathrm{h}}+\right.$ & - \\
$\left.\mathrm{E}_{\mathrm{V}}\right)$ & $\left.\mathrm{E}_{\mathrm{V}}\right)$ & - \\
$1.2 \mathrm{D}+1 \mathrm{~L}+(1.3$ & $1.2 \mathrm{D}+1 \mathrm{~L}+(1.3$ & - \\
$\left.\mathrm{QE}_{\mathrm{E}}+0.2 \mathrm{~S}_{\mathrm{DS}} \mathrm{D}\right)$ & $\left.\mathrm{Q}_{\mathrm{E}}+0.2 \mathrm{~S}_{\mathrm{DS}} \mathrm{D}\right)$ & - \\
\hline $0.9 \mathrm{D}+\mathrm{E}_{\mathrm{h}}-\mathrm{E}_{\mathrm{V}}$ & $0.9 \mathrm{D}+\mathrm{E}_{\mathrm{h}}-\mathrm{E}_{\mathrm{V}}$ & - \\
$0.9 \mathrm{D}+1.3 \mathrm{QE}-0.2$ & $0.9 \mathrm{D}+1.3 \mathrm{QE}-0.2$ & - \\
$\mathrm{S}_{\mathrm{DS}} \mathrm{D}$ & $\mathrm{S}_{\mathrm{DS}} \mathrm{D}$ & \\
\hline \multicolumn{2}{|c|}{ Load combination impacted by vertical earthquake } \\
\hline $1.2482 \mathrm{D}+1 \mathrm{~L}+1$ & $1.25 \mathrm{D}+1 \mathrm{~L}+1 \mathrm{E}_{\mathrm{h}}$ & 0,144 \\
$\mathrm{E}_{\mathrm{h}}$ & $0.85 \mathrm{D}+1 \mathrm{E}_{\mathrm{h}}$ & 0,211 \\
\hline $0.8518 \mathrm{D}+1 \mathrm{E}_{\mathrm{h}}$ &
\end{tabular}

As seen in Table 3, entering the vertical earthquake load value can provide a different combination of the two standards. With an increase in $\mathrm{S}_{\mathrm{DS}}$ by $5.52 \%$, there is an increase in both load combinations of earthquake loading by $0.469 \%$ and $0.797 \%$. So it affects the dead load on the building.

\subsection{Structure Behaviors (Internal Forces)}

With the static (dead and live) load and spectral response of SNI 1726:2012 and 2019 which have been defined in the computer software, SAP2000, the calculation and analysis can be done. Then, the values of internal forces $M_{u}, V_{u}$, and $P_{u}$, as shown in Fig. 6, are compared.

As can be seen in Table 4, the results of internal forces as a whole show that the new code is higher than the results of the old code in the method of spectrum response. The axial force and bending moment of columns in SNI 1726:2019 increased by $3.98 \%$ and $2.13 \%$, respectively, from the old standard. There is also an increase in shear force values of columns about $1.52 \%$.

The bending moment and shear force values of primary beam B1 are rising by $17.08 \%$ and $6.4 \%$ in SNI 
1726:2019, respectively. While the secondary beams B2 have little rising than the B1, it is about $7.85 \%$ and $4.88 \%$ for bending moment and shear force, respectively, from the old standard. From the structural response calculation, the building structure can be categorized as still enough to resist the seismic forces based on the latest design method, even though there is an increase in the structure's internal forces. The building structure is strong enough, so it does not need to be given rehabilitation for the earthquake loads that will occur.
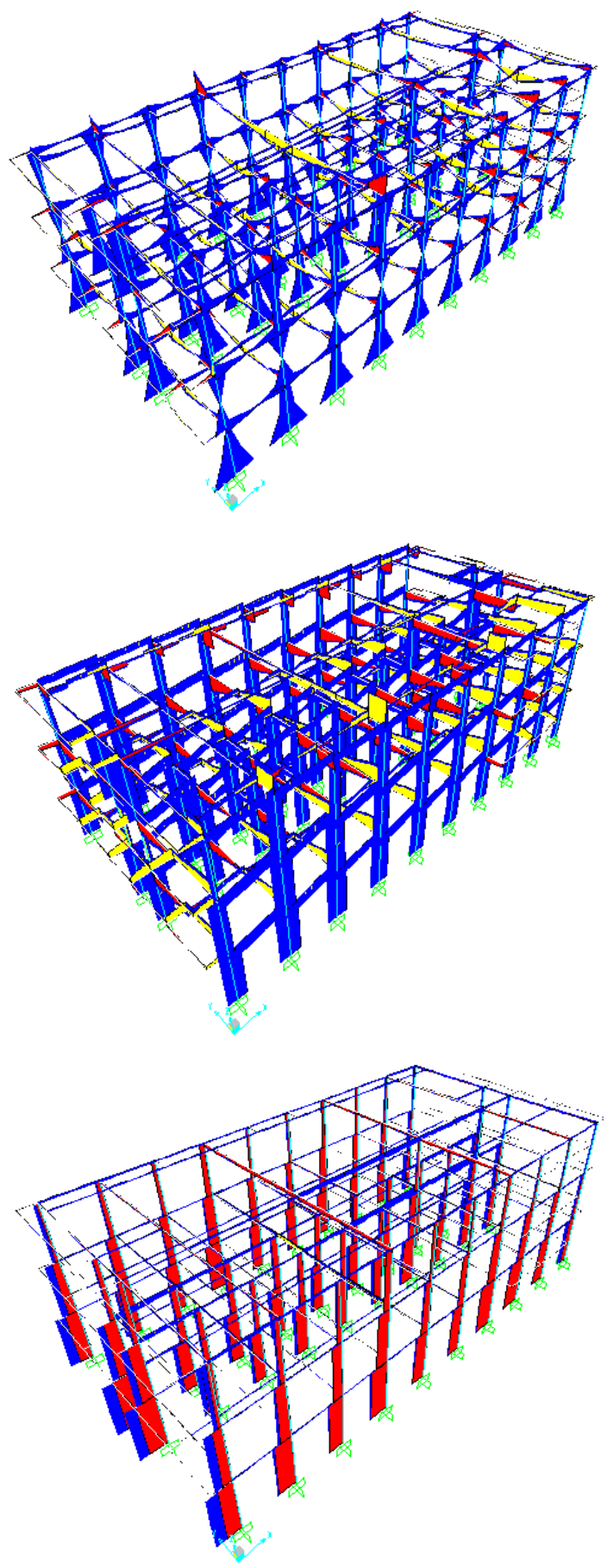

Fig. 6. Internal force (bending moment, shear, and axial forces) diagram of the building structure in Max Comb.

To obtain the reinforcement ratio $(\rho)$, calculations were carried out using $M_{u}$ data obtained in the structure model. After obtaining the amount of reinforcement at each left, right, and mid-spans; the design moment strength $\left(\varnothing M_{n}\right)$ calculates. Stirrups in the field area (from $1 / 4 \mathrm{~L}$ to $1 / 2 \mathrm{~L}$ from the left/ right), the value of $\mathrm{V}_{\mathrm{u}}=164,2$ $\mathrm{kN}$ in the area $\mathrm{L}$ to support is greater than $\mathrm{V}_{\mathrm{c}}$ so shear reinforcement must be provided using the maximum $a_{v} / s$ equation for Beam B1. The distance between stirrups and reinforcement in the field area uses D10 - 150. The design of the Beam B1 using the requirements of the SNI 2847:2019 regulations has met the requirements set out in the standard starting from the dimensions, reinforcement design, and calculation of the design moment strength $\left(\varnothing \mathrm{M}_{\mathrm{n}}\right)$, where the details of Beam B1 can be seen in Table 5 [12].

Table 4. Comparison of beams and columns internal forces between SNI 1726:2012 and 2019.

\begin{tabular}{|c|c|c|c|c|}
\hline Element & $\begin{array}{c}\text { Internal } \\
\text { Forces }\end{array}$ & $\begin{array}{r}\text { SNI } \\
2012 \\
\end{array}$ & $\begin{array}{c}\text { SNI } \\
2019\end{array}$ & $\begin{array}{c}\text { Differ } \\
\text { ent }\end{array}$ \\
\hline \multirow{3}{*}{$\begin{array}{l}\text { K1 1st } \\
\text { floor Ext }\end{array}$} & $\mathrm{Pu}(\mathrm{kg})$ & 71403,4 & 72871,8 & $2,0 \%$ \\
\hline & $\mathrm{Vu}(\mathrm{kg})$ & 7415,3 & 7491,1 & $1,0 \%$ \\
\hline & $\mathrm{Mu}$ (ton.m) & 23,9 & 24,3 & $1,6 \%$ \\
\hline \multirow{3}{*}{$\begin{array}{l}\text { K1 2nd } \\
\text { floor Ext }\end{array}$} & $\mathrm{Pu}(\mathrm{kg})$ & 46894,7 & 48363,1 & $3,0 \%$ \\
\hline & $\mathrm{Vu}(\mathrm{kg})$ & 6375,9 & 6618,6 & $3,7 \%$ \\
\hline & $\mathrm{Mu}$ (ton.m) & 13,1 & 13,4 & $2,2 \%$ \\
\hline \multirow{3}{*}{$\begin{array}{l}\text { K1 3rd } \\
\text { floor Ext }\end{array}$} & $\mathrm{Pu}(\mathrm{kg})$ & 23500,8 & 25214,0 & $6,8 \%$ \\
\hline & $\mathrm{Vu}(\mathrm{kg})$ & 4462,73 & 4492,9 & $0,7 \%$ \\
\hline & $\mathrm{Mu}$ (ton.m) & 12,7 & 13,1 & $3,1 \%$ \\
\hline \multirow{3}{*}{$\begin{array}{l}\text { K1 1st } \\
\text { floor Int }\end{array}$} & $\mathrm{Pu}(\mathrm{kg})$ & 75560,5 & 77028,9 & $1,9 \%$ \\
\hline & $\mathrm{Vu}(\mathrm{l}$ & 8295,5 & 8360,3 & $0,8 \%$ \\
\hline & $\mathrm{Mu}$ (ton & 26,8 & 27,1 & $1,1 \%$ \\
\hline \multirow{3}{*}{$\begin{array}{l}\text { K1 2nd } \\
\text { floor Int }\end{array}$} & $\mathrm{Pu}(\mathrm{kg})$ & 47756,4 & 49469,6 & $3,5 \%$ \\
\hline & $\mathrm{Vu}(\mathrm{kg})$ & 7142,8 & 7347,8 & $2,8 \%$ \\
\hline & $\mathrm{Mu}$ (ton.m) & 14,5 & 14,9 & $2,7 \%$ \\
\hline \multirow{3}{*}{$\begin{array}{l}\text { K1 3rd } \\
\text { floor Int }\end{array}$} & $\mathrm{Pu}($ & 23987,0 & 25700,1 & $6,7 \%$ \\
\hline & $\mathrm{Vu}(\mathrm{kg})$ & 4966,1 & 4970,9 & $0,1 \%$ \\
\hline & $\mathrm{Mu}$ (ton.m) & 14,2 & 14,5 & $2,1 \%$ \\
\hline \multirow{2}{*}{$\begin{array}{c}\text { B1 1st } \\
\text { floor Ext }\end{array}$} & $\mathrm{Vu}(\mathrm{k}$ & 155,0 & 164,2 & $5,6 \%$ \\
\hline & $\mathrm{Mu}(\mathrm{kI}$ & 151,8 & 208,6 & $27,2 \%$ \\
\hline \multirow{2}{*}{$\begin{array}{c}\text { B1 2nd } \\
\text { floor Ext }\end{array}$} & $\mathrm{Vu}(\mathrm{kN})$ & 141,7 & 150,5 & $5,8 \%$ \\
\hline & $\mathrm{Mu}(\mathrm{kN} . \mathrm{m})$ & 208,9 & 226,7 & $7,9 \%$ \\
\hline \multirow{2}{*}{$\begin{array}{c}\text { B1 3rd } \\
\text { floor Ext }\end{array}$} & $\mathrm{Vu}(\mathrm{kN})$ & 158,8 & 168,1 & $5,5 \%$ \\
\hline & $\mathrm{Mu}(\mathrm{kN}$ & 214,8 & 222,1 & $3,3 \%$ \\
\hline \multirow{2}{*}{$\begin{array}{c}\text { B1 1st } \\
\text { floor Int }\end{array}$} & & 158 & 16 & $5,5 \%$ \\
\hline & $\mathrm{Mu}(\mathrm{kN} . \mathrm{m})$ & 152,2 & 222,1 & $31,5 \%$ \\
\hline \multirow{2}{*}{$\begin{array}{l}\text { B1 2nd } \\
\text { floor Int }\end{array}$} & $\mathrm{Vu}(\mathrm{kN})$ & 130,8 & 139,6 & $6,3 \%$ \\
\hline & $\mathrm{Mu}(\mathrm{kN} . \mathrm{m})$ & 171,6 & 180,6 & $5,0 \%$ \\
\hline \multirow{2}{*}{$\begin{array}{l}\text { B1 3rd } \\
\text { floor Int }\end{array}$} & $\mathrm{Vu}(\mathrm{kN})$ & 148,3 & 164,2 & $9,7 \%$ \\
\hline & $\mathrm{Mu}(\mathrm{k}$ & 151,3 & 209,1 & $27,6 \%$ \\
\hline \multirow{2}{*}{$\begin{array}{c}\text { B2 1st } \\
\text { floor Ext }\end{array}$} & $\mathrm{Vu}(\mathrm{kN})$ & 65,0 & 65,7 & $1,1 \%$ \\
\hline & $\mathrm{Mu}(\mathrm{kN} . \mathrm{m})$ & 92,7 & 93,8 & $1,2 \%$ \\
\hline \multirow{2}{*}{$\begin{array}{l}\text { B2 2nd } \\
\text { floor Ext }\end{array}$} & $\mathrm{Vu}(\mathrm{kN})$ & 64,1 & 64,3 & $0,3 \%$ \\
\hline & $\mathrm{Mu}(\mathrm{kN}$. & 83,7 & 91,2 & $8,2 \%$ \\
\hline \multirow{2}{*}{$\begin{array}{c}\text { B2 3rd } \\
\text { floor Ext }\end{array}$} & $\mathrm{Vu}(\mathrm{kN})$ & 49,6 & 52,9 & $6,2 \%$ \\
\hline & $\mathrm{Mu}(\mathrm{kN} . \mathrm{m})$ & 58,0 & 65,9 & $12,0 \%$ \\
\hline \multirow{2}{*}{$\begin{array}{c}\text { B2 1st } \\
\text { floor Int }\end{array}$} & $\mathrm{Vu}(\mathrm{kN})$ & 64,1 & 64,4 & $0,5 \%$ \\
\hline & $\mathrm{Mu}(\mathrm{kN} . \mathrm{m})$ & 86,1 & 91,3 & $5,7 \%$ \\
\hline \multirow{2}{*}{$\begin{array}{l}\text { B2 2nd } \\
\text { floor Int }\end{array}$} & $\mathrm{Vu}(\mathrm{kN})$ & 48,3 & 55,7 & $13,3 \%$ \\
\hline & $\mathrm{Mu}(\mathrm{kN} . \mathrm{m})$ & & 83,7 & $3,8 \%$ \\
\hline \multirow{2}{*}{$\begin{array}{l}\text { B2 3rd } \\
\text { floor Int }\end{array}$} & $\mathrm{Vu}(\mathrm{kN})$ & 50,7 & 55,7 & $9,0 \%$ \\
\hline & $\mathrm{Mu}$ (kN.m) & 66,6 & 80,6 & $17,4 \%$ \\
\hline
\end{tabular}

Table 5. Comparison of column and beams design between SNI 2847-2019 and existing building. 


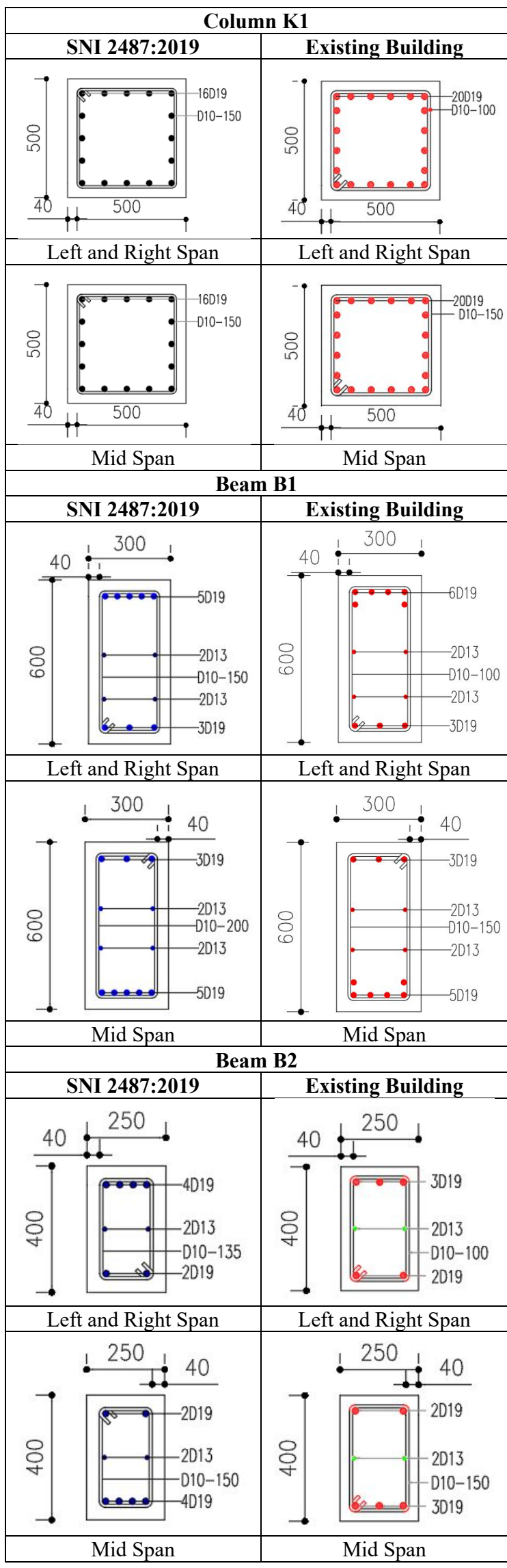

Based on the calculation results of the interaction diagram, the Column $\mathrm{K} 1$ being monitored is still safe because $M_{n}>M_{u}$; where $M_{n}=573.5$ kN.m and $M_{u}=244.2$ $\mathrm{kN} . \mathrm{m}$ ), and the strong column of the weak beam is fulfilled. For structures with $\mathrm{Pu}<0.3 \mathrm{Ag} \mathrm{fc}^{\prime}$, the total cross-sectional area of square stirrup reinforcement is taken as the largest value. After calculating Column K1 using the requirements of the SNI 2847:2019 regulation, it has fulfilled the requirements set out in the regulation starting from the dimensions, reinforcement design, and calculation of the moment strength design $\left(\varnothing M_{n}\right)$, where the details of Column $\mathrm{K} 1$ can be seen in Table 5. $\mathrm{A}_{\mathrm{s}}$ needed $=3,6.10^{5} \mathrm{~mm}^{2}$ (result of SAP2000) and 16D19 flexural reinforcement is used.

Results the design of beams, columns, and slab after being redesigned with SNI 2847:2019 for dimensions already meets the requirements, but for flexural reinforcement and shear reinforcement obtained after being designed, changes are made, such as the example in Beam B2 in the initial conditions used flexural reinforcement 3D19 and after redesign used 4D19.

\section{Conclusions}

From the above calculation and discussion, there is an effect of changing the design plan of SNI 1726:2012 to SNI 1726:2019. In the spectrum response design, the $\mathrm{S}_{\mathrm{DS}}$ and $\mathrm{S}_{\mathrm{D} 1}$ parameters in SNI 1726:2019 increased by 3.60\% and $19.02 \%$, respectively, from the old standard. By this rising, it affects the response spectra graph that has increased in SNI 1726:2019. For internal forces of structural elements, the axial force and bending moment of columns increased about $3.98 \%$ and $2.13 \%$, respectively. The increase is also occurring in their shear forces by $1.52 \%$. The bending moment and shear force values are rising by $17.08 \%$ and $6.4 \%$ for Beam B1; $7.85 \%$ and $4.88 \%$ for Beam B2, respectively.

The design of the Beam B1 using the requirements of the SNI 2847:2019 standard has met the requirements set out in the standard starting from the dimensions, reinforcement design, and calculation of the design moment strength $\left(\mathrm{M}_{\mathrm{n}}\right)$. The Column K1 being monitored is still safe because $M_{n}>M_{u}$ and the strong column of the weak beam is fulfilled. Results the design of beams, columns, and slabs after being redesigned with SNI 2847:2019 for dimensions already meets the requirements, but for flexural reinforcement and shear reinforcement obtained after being designed, changes are made, such as Beam B2; in the initial conditions used reinforcement 3D19 and after redesign used 4D19.

The calculation of the GKT II Building structure uses the old code designing but it still meets the safe limits using designing with the new codes, SNI 1726:2019 and SNI 2847:2019 methods. Overall, the building structure can be classified as able to withstand seismic force corresponding to the latest standards.

This study was financially supported by Pusat Penelitian dan Pengabdian Masyarakat (P3M) Bengkalis State Polytechnic Indonesia through Research Grant 2021.

\section{References}

1. P. Pudjisuryadi, E.D. Mulyadi, Ferry, B. Lumantarna, Performance of an existing reinforced concrete 
building designed in accordance to older Indonesian codes (PPTGIUG 1983 SK SNI T-15-1991-03): a case study for a hotel in Balikpapan, MATEC Web of Conferences 258, 05028 (2019)

2. National Standardization Agency, SNI 1726-2012, Procedures for Planning Earthquake Resistance for Non-Building Building Structures, BSN, Jakarta, Indonesia (2012)

3. National Standardization Agency, SNI 1726-2019 Procedures for Planning Earthquake Resistance for Non-Building Building Structures, BSN, Jakarta, Indonesia (2019)

4. S. Arifah, D.J. Jaya, S. Widodo, Comparative study of internal force in lecture buildings in Daerah Istimewa Yogyakarta between SNI 1726-2012 and 1726-2019 with the spectrum response method (2D), Journal of Physics: Conference Series 1833 (2021) 012026

5. S.G. Makarande, V. V. Agrawal, G.D. Dhawale, A.B. Dehane, M.R. Nikhar, Analysis and Design of Multi Storeyed Building using Staad Pro and Manually for Two Seismic Zones, Iconic Research and Engineering Journals, 3, Issue 3 (2019)

6. G.G. Kakpure, A. R. Mundhada, Comparative Study of Static and Dynamic Seismic Analysis of Multistoried RCC Buildings by ETAB, Int. Journal of Engineering Research and Application, 7 (5), 5, 6-10 (2017)
7. Ayuddin, Global structural analysis of high-rise hospital building using earthquake-resistant design approach, SINERGI, 24 (2), 95-108 (2020)

8. Z.A. Jauhari, Armada, F. Ananda, R. A. Fitrah, Comparison of the design acceleration response spectra in Riau Province between SNI 1726:2019 and SNI 1726:2012 Methods, IOP Conf. Series: Earth and Environmental Science 708012009 (2021)

9. R.A. Fitrah, D.I. Mazni, W. Pratiwi, Z.A. Jauhari, Seismic assessment of irregularities in steel special moment resisting frame with asymmetric-plan building (case study: Gedung D - Universitas Dharma Andalas), IOP Conf. Series: Earth and Environmental Science 708012007 (2021)

10. G. H. Powell, R. Allahabadi, Seismic damage prediction by deterministic methods: concepts and procedures, Earthquake Engineering \& Structural Dynamics (1988)

11. D.J. Jaya, S. Arifah, S. Widodo, Review of internal force magnitude at the 5-floor hospital in North Sulawesi Province between SNI 1726-2012 and SNI 1726-2019 with response spectrum (2D) method, IOP Conference Series: Earth and Environmental Science (2021)

12. National Standardization Agency, SNI 2847-2019 Structural Concrete Requirements for Buildings, , BSN, Jakarta, Indonesia (2019) 